\title{
TINKLAINĖS VENOS TROMBOZE்: RIZIKOS VEIKSNIAI, DIAGNOSTIKA, GYDYMAS
}

\author{
Donatas Savičius \\ Vilniaus universiteto Medicinos fakultetas
}

\begin{abstract}
Raktažodžiai: tinklainès venos trombozè, rizikos veiksniai, diagnostika ir gydymas.

Santrauka

Tinklainès venos trombozè - antra pagal dažnumą regos praradimo priežastis dèl tinklainès kraujagyslinių ligų, dažnumu nusileidžianti tik diabetinei retinopatijai. Tinklainès venos trombozès pasireiškimo rizika didejja su amžiumi. Tinklainès venos trombozè pasireiškia ūminiu ir dažnai negrįžtamu regos praradimu, todèl svarbu laiku diagnozuoti ir skirti tinkamą gydymą. Gydymo tikslas - komplikacijų, paveikiančių regos aštrumą, korekcija ir prevencija. Šio tyrimo tikslas - išanalizuoti bei aptarti ịrodymais pagrịstą informaciją apie tinklainès venos trombozès rizikos veiksnius, diagnostiką ir gydymą.
\end{abstract}

\section{Ivadas}

Tinklainės venos trombozè (TVT) - antra pagal dažnumą regos praradimo priežastis dèl tinklainès kraujagyslinių ligų, dažnumu nusileidžianti tik diabetinei retinopatijai. 2015 metu duomenimis, TVT paplitimas pasaulyje siekè 28.06 milijonus ligos atvejų, nepriklausomai nuo lyties ar kitų veiksnių [1]. Pagal lokalizaciją skiriami 2 pagrindiniai TVT tipai - centrinès tinklainès venos ir distalinių tinklainès venos šakų trombozè. Tinklainès venų trombozè išsivysto dèl susidariusio kraujo krešulio kraujagyslès spindyje. Pirminio trombo susidarymui itakos turi mikrocirkuliacijos sutrikimai, arterinis spazmas ir aplinkinių kraujagyslių suspaudimas. TVT pasireiškia ūminiu ir dažnai negrižžtamu regos praradimu, todèl svarbu laiku diagnozuoti ir skirti tinkamą gydymą. Gydymo tikslas - komplikacijų, paveikiančių regos aštrumą, korekcija ir prevencija.

Tyrimo tikslas - išanalizuoti bei aptarti ịrodymais pagrịstą informaciją apie centrinès tinklainès venos trombozès rizikos veiksnius, diagnostiką bei gydymą.

\section{Tyrimo medžiaga ir metodai}

Taikyta sisteminė mokslinès literatūros bei dokumentų apžvalga ir analizè. Duomenų buvo ieškoma Google Scholar, UpToDate, Cochrane bei Medline (PubMed) duomenų bazėse.
Visateksčiai straipsniai atrinkti, jei jų pavadinimas, santrauka ar reikšminiai žodžiai nurodè, kad tyrimas tinkamas ittraukti i šią apžvalgą. Pasirinktos tik anglų kalba skelbtos publikacijos. Vartoti nurodyti raktažodžiai. Atrinkti, išanalizuoti ir apibendrinti 7 straipsniai.

\section{Tyrimo rezultatai}

Rizikos veiksniai. Pagrindiniams TVT rizikos veiksniams priskiriamas amžius, pirminė arterinè hipertenzija (PAH), šrdies ir kraujagyslių ligos, dislipidemija ir diabetas, o rūkymas, nutukimas, atviro kampo glaukoma ir kontraceptiku vartojimas priskiriami mažiau svarbiems rizikos veiksniams. Nustatyta, kad svarbiausias rizikos veiksnys - amžius. 49-60 metų amžiaus grupejje TVT dažnis $-0,7$ proc., vyresnių nei 80 metų amžiaus grupeje $-4,6$ procento [1]. Naujausių tyrimų duomenimis, PAH pasireiškia 48 proc. TVT atvejų, dislipidemija - 20 proc., o diabetas -5 procentais. Atviro kampo glaukoma yra svarbiausias oftalmologinis rizikos veiksnys, susijęs su centrinès TVT susidarymo rizika. Sisteminiai rizikos veiksniai sukelia didesnę distalinių tinklainès venos šakų trombozės išsivystymo riziką, lyginant su centrinès TVT išsivystymo rizika [2].

Diagnostika. TVT diagnostika remiasi būdingų klinikinių simptomų atpažinimu, tipiniu akies dugno vaizdu oftalmoskopuojant ir papildomai atliekamų kitų instrumentinių tyrimų duomenimis [3]. TVT atveju atsiranda vienos akies beskausmis ūminis regos pablogèjimas, galintis pasireikšti kaip skotoma ar išblukęs ir bespalvis vaizdas. Regos sutrikimas pasireiškia ne taip staiga, kaip centrinès tinklainès arterijos nepraeinamumo atveju - rega gali laipsniškai blogèti keletą valandų ar dienų, regos sutrikimą sukelia geltonosios demès edema [4]. TVT atveju matomas būdingas oftalmoskopinis vaizdas - išsiplètusios ir vingiuotos tinklainès venos, difuzinès kraujosruvos visoje tinklainèje, paburkęs regos nervas ir tinklainè bei geltonosios dèmès išemija ir paburkimas. Papildomai gali būti atliekama fluorescenciné angiografija tiksliausiam kapiliarų okliuzijos ploto nustatymui ir optiné koherentinè tomografija geltonosios dėmès edemos vertinimui [3]. 
Gydymas. TVT gydymo taktika ir baigtis priklauso nuo perfuzijos sutrikimo laipsnio, pagal kurị TVT skirstoma ị išeminę ir neišeminę. Neišeminė TVT yra dažniausia (iki $75 \%$ atvejų), jai būdingas vidutiniškai susilpneję̨s regejjimo aštrumas, matomi nežymūs pakitimai. Išeminè TVT pasireiškia žymiu regėjimo aštrumo sumažèjimu, jos atveju matomi ryškūs tinklainès išemijai būdingi pakitimai - gausios tinklainès kraujosruvos centre ir periferijoje, galimi balkšvi minkšti židiniai, plazmoragijos; ryškus regos disko paburkimas ir hiperemija; geltonoji dèmè paburkusi, matomos kraujosruvos; fluorescencinè angiografija rodo hemoragijomis pasidengusias tinklainès kraujagysles ir didelius neperfuzuojamus plotus [4]. Neišeminès TVT atveju dauguma ūminių požymių išnyksta per 6-12 mėnesių, palaipsniui gali atsirasti regos disko kolateralių, epiretinalinių membranų, pigmentinių geltonosios dèmés pakitimų, kartais gali virsti išemine TVT. Jei nevirsta išemine - prognozė gera, 50 proc. pacientų regèjimo aštrumas normalizuojasi arba tampa beveik normalus. Pagrindinè blogos regos priežastis - lètinè cistinè geltonosios dèmès edema. Jei per 3 mèn. geltonosios dèmès paburkimas nesirezorbuoja, būtina lazerio koaguliacija. Išeminès TVT atveju regèjimo aštrumo pablogejjimas gali išlikti dèl persistuojančios geltonosios dèmės išemijos. Negydant išlieka didelè komplikacijų rizika - antrinès neovaskulinès glaukomos, rainelès rubeozės, kraujo išsiliejimo ị stiklakūnị ir lokalios trakcinès tinklainès atšokos neovaskuliarizacijos arba preretinalinès membranos zonoje. Gydymo taktika remiasi tuo, ar stebima geltonosios demès edema ir neovaskuliarizacija [5]. Nesant geltonosios dèmès edemos ar neovaskuliarizacijos, būklei stabilizavusis, pakanka pacientų stebejjimo bent 6-12 mėnesių. Esant geltonosios dèmès edemai, skiriamos periodinès anti-VEGF injekcijos ị stiklakūnį; alternatyva - gliukokortikoidai [6]. Nustačius neovaskuliarizaciją, taikoma taškinè koaguliacija lazeriu arba chirurginis gydymas [7].

\section{Išvados}

1. Amžius, pirminė arterinè hipertenzija, dislipidemija ir diabetas yra pagrindiniai tinklainès venos trombozès rizikos veiksniai.

2. Tinklainès venos trombozès diagnozė gali būti nustatoma pagal būdingus klinikinius požymius ir oftalmoskopini vaizdą. Papildomi tyrimai padeda ịvertinti ligos sunkumą ir prognozę.

3. Tinklainès venos trombozès gydymo taktika ir baigtis priklauso nuo perfuzijos sutrikimo laipsnio.

\section{Literatūra}

1. Song P, Xu Y, Zha M, Zhang Y, Rudan I. Global epidemiology of retinal vein occlusion: a systematic review and meta-analysis of prevalence, incidence, and risk factors. J Glob Health
2019;9(1):010427.

https://doi.org/10.7189/jogh.09.010427

2. Kolar P. Risk factors for central and branch retinal vein occlusion: a meta-analysis of published clinical data. Journal of Ophthalmology 2014;2014:e724780.

https://doi.org/10.1155/2014/724780

3. Han DP, Ahmad B. Retinal vein occlusion: epidemiology, clinical manifestations, and diagnosis - UpToDate 2021. https://www. uptodate.com/contents/retinal-vein-occlusion-epidemiologyclinical-manifestations-and-diagnosis?search=retinal $\% 20$ vein $\% 20$ occlusion\&source $=$ search result\&selectedTitle $=1 \sim$ $150 \&$ usage_type $=$ default\&display_rank $=1$

4. Yau JWY, Lee P, Wong TY, Best J, Jenkins A. Retinal vein occlusion: an approach to diagnosis, systemic risk factors and management. Internal Medicine Journal 2008;38(12):904-10. https://doi.org/10.1111/j.1445-5994.2008.01720.x

5. Han DP, Ahmad B. Retinal vein occlusion: treatment. UpToDate 2021. https://www.uptodate.com/contents/retinal-vein-occlusion-treatment?search $=$ retinal $\% 20$ vein $\% 20$ occlusion\&source $=$ search_result\&selectedTitle $=2 \sim 150 \&$ usa ge_type $=$ default\&display_rank=2\#H7612439

6. Braithwaite T, Nanji AA, Greenberg PB. Anti-vascular endothelial growth factor for macular edema secondary to central retinal vein occlusion. Cochrane Database Syst Rev 2010;(10):CD007325.

https://doi.org/10.1002/14651858.CD007325.pub2

7. La Spina C, De Benedetto U, Parodi MB, Coscas G, Bandello F. Practical management of retinal vein occlusions. Ophthalmol Ther 2012;1(1).

https://doi.org/10.1007/s40123-012-0003-y

\section{RETINAL VEIN OCCLUSION - RISK FACTORS, DIAGNOSIS AND TREATMENT}

\section{Savičius}

Keywords: retinal vein occlusion, risk factors, diagnosis and treatment of retinal vein occlusion

Summary

Retinal vein occlusion is the second most common cause of visual impairment due to retinal disease after diabetic retinopathy. The prevalence of retinal vein occlusion (RVO) increases with age. Seeing that retinal vein occlusion results in acute and, in most cases, permanent visual loss, it is important to diagnose and treat this condition immediately. Management is directed at secondary complications of retinal vein occlusion that affect vision. The aim of this study was to evaluate, systematize and analyze the data presented in the scientific literature on risk factors of retinal vein occlusion, diagnostic evaluation, and treatment.

Conclusions. 1. Major risk factors for retinal vein occlusion are age, hypertension, dyslipidemia and diabetes. 2 . The diagnosis of retinal vein occlusion can be based on a characteristic clinical symptoms and findings on ophthalmologic examination. Additional examination can help evaluate the severity and prognosis of the disease. 3. Management of retinal vein occlusion depends on the severity of the disease.

Correspondence to: donatassavicius@gmail.com

Gauta 2021-04-25 